\title{
The importance of Northern Peatlands in global carbon systems during the Holocene
}

\author{
Y. Wang ${ }^{1,2}$, N. T. Roulet ${ }^{2}$, S. Frolking ${ }^{3}$, and L. A. Mysak ${ }^{4}$ \\ ${ }^{1}$ Department of Geography, University of Sussex, Falmer, Brighton, BN1 9SJ, UK \\ ${ }^{2}$ Dept. of Geography and McGill School of Environment, McGill Univ., 3534 Univ., Montreal, Quebec H3A 2A7, Canada \\ ${ }^{3}$ Institute for the Study of Earth, Oceans, and Space, University of New Hampshire, Durham, NH 03824, USA \\ ${ }^{4}$ Dept. of Atmospheric and Oceanic Sciences, McGill University, 805 Sherbrooke Street West, Montreal, \\ Quebec H3A 2K6, Canada
}

Received: 26 March 2009 - Published in Clim. Past Discuss.: 23 April 2009

Revised: 3 October 2009 - Accepted: 10 October 2009 - Published: 11 November 2009

\begin{abstract}
We applied an inverse model to simulate global carbon $(\mathrm{C})$ cycle dynamics during the Holocene period using atmospheric carbon dioxide $\left(\mathrm{CO}_{2}\right)$ concentrations reconstructed from Antarctic ice cores and prescribed $\mathrm{C}$ accumulation rates of Northern Peatlands (NP) as inputs. Previous studies indicated that different sources could contribute to the 20 parts per million by volume (ppmv) atmospheric $\mathrm{CO}_{2}$ increase over the past 8000 years. These sources of C include terrestrial release of 40-200 petagram C ( $\mathrm{PgC}, 1$ petagram $=10^{15} \mathrm{gram}$ ), deep oceanic adjustment to a $500 \mathrm{PgC}$ terrestrial biomass buildup early in this interglacial period, and anthropogenic land-use and land-cover changes of unknown magnitudes. Our study shows that the prescribed peatland $\mathrm{C}$ accumulation significantly modifies our previous understanding of Holocene $\mathrm{C}$ cycle dynamics. If the buildup of the NP is considered, the terrestrial pool becomes the C sink of about $160-280 \mathrm{PgC}$ over the past 8000 years, and the only $\mathrm{C}$ source for the terrestrial and atmospheric $\mathrm{C}$ increases is presumably from the deep ocean due to calcium carbonate compensation. Future studies need to be conducted to constrain the basal times and growth rates of the NP C accumulation in the Holocene. These research endeavors are challenging because they need a dynamically-coupled peatland simulator to be constrained with the initiation time and reconstructed $\mathrm{C}$ reservoir of the NP. Our results also suggest that the huge reservoir of deep ocean $\mathrm{C}$ explains the major variability of the glacial-interglacial $\mathrm{C}$ cycle dynamics without considering the anthropogenic $\mathrm{C}$ perturbation.
\end{abstract}

Correspondence to: Y. Wang

(ywang699@gmail.com)

\section{Motivation}

An intriguing atmospheric carbon dioxide $\left(\mathrm{CO}_{2}\right)$ reconstruction (Fig. 1) from the Antarctic ice cores (Indermühle et al., 1999; Monnin et al., 2001; Luthi et al., 2008) has attracted broad attention from the paleoclimatic community (Beerling, 2000; Broecker et al., 1999, 2001; Brovkin et al., 2002; Broecker and Clark, 2003; Ruddiman, 2003; Joos et al., 2004; Wang et al., 2005c; Broecker and Stocker, 2006; Ruddiman, 2006, 2007, 2008; Brovkin et al., 2008). What are the sources of this 20 -ppmv $\mathrm{CO}_{2}$ increase during the last eight thousand years (hereafter, $8 \mathrm{ka}$ )? Indermühle et al. (1999), using an inverse method, suggest that most of the variability in atmospheric $\mathrm{CO}_{2}$ is caused by the terrestrial $\mathrm{C}$ pool releasing about 200 petagram $\mathrm{C}\left(\mathrm{PgC}, 1\right.$ petagram $=10^{15}$ gram $)$ during the past $8 \mathrm{ka}$, and a sea surface temperature (SST) increase of about $0.5^{\circ} \mathrm{C}$. A change of SST by $1^{\circ} \mathrm{C}$ causes a change in the surface ocean's $\mathrm{CO}_{2}$ partial pressure by $4.2 \%$, which translates into an atmospheric change of similar magnitude (Bacastow, 1996). Based on the study of Joos et al. (2004), a $0.5^{\circ} \mathrm{C}$ increase of global SST during the Holocene will contribute to an oceanic outgassing of $\mathrm{CO}_{2}$ (about 5 ppmv).

Broecker et al. $(1999,2001)$ propose that the atmospheric $\mathrm{CO}_{2}$ increase is, in part, due to an oceanic adjustment to a $500 \mathrm{PgC}$ accumulation that occurred early in the present interglacial. Broecker et al. (2001) argue that the $\mathrm{CO}_{2}$ released from the ocean-atmosphere reservoir is used for the growth of terrestrial biosphere during early postglacial time (e.g., before $8 \mathrm{ka}$ before present, hereafter $8 \mathrm{kaBP}$ ). The restoration of this $500 \mathrm{PgC}$ terrestrial biomass would have caused a large increase in the carbonate ion concentration in the deep ocean, and a deepening of the saturation level of calcite (i.e.,

Published by Copernicus Publications on behalf of the European Geosciences Union. 
Atmospheric $\mathrm{CO}_{2}$ Concentration Ice Core Data
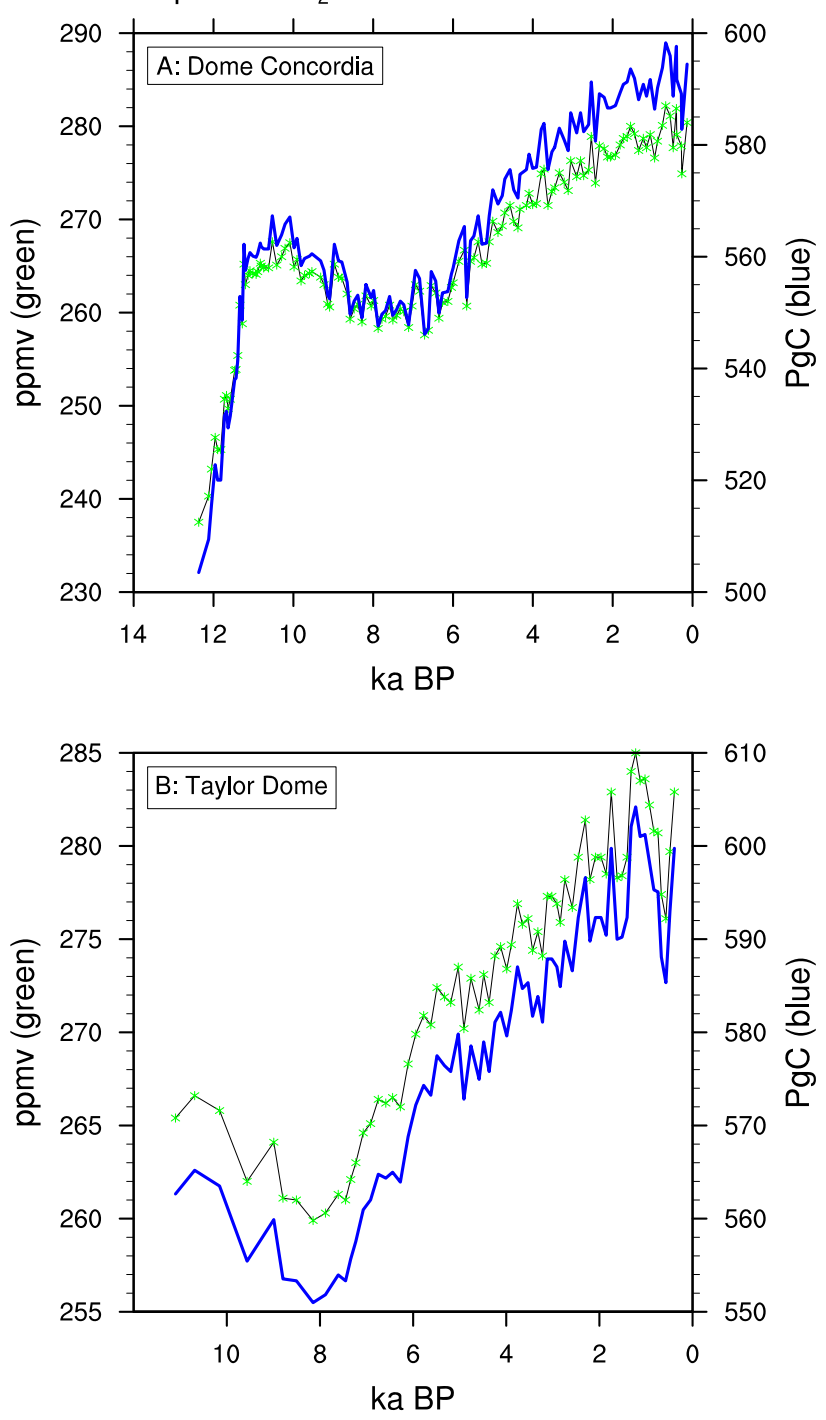

Fig. 1. Ice core derived atmospheric $\mathrm{CO}_{2}$ concentration (green curves) and corresponding $\mathrm{C}$ storage in $\mathrm{PgC}$ (blue curves) from (a) Dome Concordia, and (b) Taylor Dome (bottom). To convert ppmv to $\mathrm{PgC}$, we multiply the former by $2.12 \mathrm{PgC} / \mathrm{ppmv}$, the well-known conversion constant for the atmosphere. Note that we have utilized the updated gas-age model for Dome Concordia $\mathrm{CO}_{2}$ (Luthi et al., 2008).

lysocline). Hence the oceanic $\mathrm{CaCO}_{3}$ budget would have become imbalanced, which would induce a draw down in the carbonate ion concentration of the entire ocean, and a complementary increase in the partial pressure of $\mathrm{CO}_{2}$ in the ocean, and consequently in the atmosphere. This biomass restoration hypothesis has also ruled out the scenarios involving changes in the strength of the oceanic biology pump over the past $8 \mathrm{ka}$, because in this case, the carbonate ion concentration in the deep ocean would not have changed.
Alternatively, Ruddiman (2003, 2006, 2007, 2008) proposes that a large portion (about 9-10 ppmv) of the unexpected 40 ppmv increase (difference between 280 and an otherwise suggested pre-industrial $240 \mathrm{ppmv}$ ) during the past $8 \mathrm{ka}$ is unique, unnatural, and anthropogenic as compared with those in previous interglacial periods. While there have been human impacts on land use and/or land cover changes, the magnitudes of these changes and their biogeophysical and/or biogeochemical consequences are still uncertain.

More recently, Brovkin et al. (2008) reconstructed a complicated Holocene global SST picture that did not support a notable warming of the ocean surface as an explanation of the 20-ppmv $\mathrm{CO}_{2}$ increase during the past $8 \mathrm{ka}$. Their reconstructed net warming of SST is only about $0.2 \pm 0.2^{\circ} \mathrm{C}$, the same as simulated by Wang et al. (2005b, c). Wang et al. (2005c, hereafter WMR) use an inverse method, and find that from 8 to $6 \mathrm{ka} \mathrm{BP}$, the cause of the first $10 \mathrm{ppmv}$ increase in atmospheric $\mathrm{CO}_{2}$ is from the deep ocean, while the remaining $10 \mathrm{ppmv}$ increase from 6 to $0 \mathrm{ka} \mathrm{BP}$ is partially from the terrestrial $\mathrm{C}$ release of about $68-95 \mathrm{PgC}$. Among others, the most common feature of previous modeling studies of Holocene carbon cycle dynamics (Brovkin et al., 2002; Joos et al., 2004; Wang, 2005; Wang et al., 2005b; WMR; Brovkin et al., 2008) is the neglect of the northern (boreal and subarctic) peatlands (NP) ecosystem (Limpens et al., 2008).

The last deglaciation is accompanied by the initiation and buildup of the NP (Gorham, 1957, 1991, 1995; Halsey et al., 1998; Gajewski et al., 2001; Smith et al., 2004; MacDonald et al., 2006; Roulet et al., 2007; Gorham et al., 2007; Yu et al., 2009). The general estimated $C$ reservoir of present-day NP is about 270 to $450 \mathrm{Pg} \mathrm{C}$ (Gorham, 1991, 1995; Roulet, 2000; Turunen et al., 2002; Smith et al., 2004; MacDonald et al., 2006; Roulet et al., 2007; Limpens et al., 2008) as peat in about a 3 to 4 million $\mathrm{km}^{2}$ area. The uncertainty of the estimated $\mathrm{C}$ storage comes mainly from the average bulk $\mathrm{C}$ density (Barber et al., 2003; Yu, 2006) and mean peat depth (Turunen et al., 2002; Gorham et al., 2003). Overall, the NP has been a persistent $\mathrm{C}$ sink during the Holocene (Gorham, 1995; Turunen et al., 2002; Smith et al., 2004; MacDonald et al., 2006), and likely has caused a global cooling on the millennium scale (Frolking and Roulet, 2007). Also, undisturbed peatlands may continue serving as net $\mathrm{C}$ sinks despite the presence of large interannual variability in the area of different peatlands (Moore et al., 1998). Due to the large uncertainties associated with the initial (basal) dates, bulk $\mathrm{C}$ density, and area of development, incorporating NP in global C cycle studies in the Holocene has been a "grand" challenge.

In this paper, we attempt to establish the first-order impact of the NP C accumulation on the global $\mathrm{C}$ cycle dynamics in the Holocene by using the inverse method (see Sect. 2.2 and WMR for details) and a simple approximation of the gradual growth of the NP ecosystem (see Sect. 3 for details). The prescribed NP C trajectory is based on recent studies (Frolking et al., 2006; Frolking and Roulet, 2007) in Western Siberia (Smith et al., 2004), North America (Gorham et al., 2007), 
and Finland (Turunen et al., 2002). By assuming global C conservation on the timescale of interests, we establish the relative $\mathrm{C}$ changes in the three major reservoirs of land, atmosphere and ocean over the past $8 \mathrm{ka}$ before the pre-industrial period (hereafter $8 \mathrm{ka} \mathrm{BP}$ ). The remainder of this paper is organized as follows. In Sect. 2, we will describe, briefly, the "Green" McGill Paleoclimate Model (Wang et al., 2005a,b), the inverse method, and the experiments. The prescribed NP development is reviewed in Sect. 3. In Sect. 4, our major results are given. A summary, discussion, and future work are described in Sect. 5.

\section{Brief model description, methodology, and experiment design}

\subsection{Brief model description}

The "Green" McGill Paleoclimate Model (hereafter MPM) is a six-component (atmosphere, ocean, sea ice, land surface, ice sheet and vegetation) Earth system Model of Intermediate Complexity (EMIC, Claussen et al., 2002). The atmosphere component is a sectorially averaged energy-moisture balance model (Wang and Mysak, 2000). The ocean component is a 2.5 -D zonally averaged model based on Wright and Stocker (1991). The MPM has been developed to include biogeophysical feedbacks (Wang et al., 2005a; WMR) so that the energy and moisture fluxes and interactions between land surface and atmosphere are considered interactively. However, the biogeochemical feedbacks have not been considered interactively in the MPM except that the atmospheric $\mathrm{CO}_{2}$ concentration is used in the radiation calculation of the energy-moisture balance model (Wang and Mysak, 2000). The "Green" MPM has been used in studies of Holocene climate changes and $\mathrm{C}$ cycle dynamics (Wang et al. 2005b; WMR) with a retreating Laurentide Ice Sheet (LIS). The MPM also has been used to study the last glacial inception (Wang et al., 2005; Mysak, 2008), glacial abrupt climate changes and Dansgaard-Oeschger Oscillation (Wang and Mysak, 2006), and the next glacial inception (Cochelin et al., 2006; Mysak, 2008).

Following the approach in Wang et al. (2005b) and the reconstruction of Dyke and Prest (1986, 1987), we prescribed a retreating LIS from 8 to $6 \mathrm{kaBP}$ in our simulations. The terrestrial $\mathrm{C}$ cycle module is based on VECODE (Brovkin et al., 1997, 2002). VECODE simulates the $C$ stored in live vegetation and soil when forced by the climatic conditions (e.g., temperature and precipitation) in the model, and has been used in several studies of the Holocene (Brovkin et al., 2002; Renssen et al., 2006). The atmospheric $\mathrm{CO}_{2}$ concentration used in VECODE will have only a fertilizing effect on the net primary productivity (NPP). In addition to the atmospheric $\mathrm{CO}_{2}$, annual mean temperature and precipitation control the value of annual NPP (Brovkin et al., 1997, 2002). The pre-industrial, mid-Holocene (6 ka BP), and $8 \mathrm{ka} \mathrm{BP}$ ter- restrial C cycles in the "Green" MPM have been validated in WMR, and are in good agreement with other modeling studies (Brovkin et al., 2002; Joos et al., 2004), and observations Schimel et al. (1994) and Falloon et al. (1998).

\subsection{Methodology}

Because we do not have an oceanic $\mathrm{C}$ cycle module in the "Green" MPM, we have introduced an inverse method to close the global C cycle in our model. As shown in Fig. 2, on the timescale of interest, there are three major reservoirs in the global C cycle: (1) terrestrial vegetation and soils, (2) atmosphere, and (3) ocean (including sedimentation). Twoway fluxes (Fig. 2) can occur between land and atmosphere, and between ocean and atmosphere. However, only one-way discharge of dissolved organic and/or inorganic $\mathrm{C}$ can occur between land and ocean. As in the studies of Brovkin et al. (2002) and Joos et al. (2004), we have neglected the one-way transport of $\mathrm{C}$ from land to ocean. Our goal is to conserve the global $\mathrm{C}$ storage in the following simulations. In our simulations, the oceanic $\mathrm{C}$ pool (including sedimentation) is considered as a box whose content is varied to compensate the changes in (1) atmospheric $\mathrm{C}$ storage based on ice core data (Indermühle et al., 1999; Monnin et al., 2001), (2) simulated terrestrial C storage by VECODE, and (3) a prescribed NP development based on Sect. 3 .

We use this inverse method as follows: (1) If both atmospheric and land (including NP) C storages increase during the Holocene, we can infer that the only source of this atmospheric $\mathrm{C}$ increase must come from the ocean because of the C fluxes as shown in Fig. 2; (2) However, if atmospheric C storage increases, while the land $\mathrm{C}$ storage decreases during the Holocene, we cannot uniquely determine the source of this atmospheric $\mathrm{C}$ increase (WMR) because the land is releasing $\mathrm{C}$ to the atmosphere, together with the ocean. This is because there are two-way fluxes between land and atmosphere and between ocean and atmosphere. To this end, additional assumptions (see e.g., WMR) are needed to clarify the source of atmospheric $\mathrm{C}$ changes. Also notice that we do not include (test) the hypothesis of Ruddiman (2003, 2006, 2007, 2008), which proposes anthropogenic land-use and/or land-cover changes as potential sources of the atmospheric $\mathrm{C}$ increase during the Holocene.

\subsection{Experimental design}

The atmosphere, land surface, and sea ice components of the "Green" MPM, together with VECODE, are first spun up for 60 years under the forcings of (1) monthly mean insolation at the top of the atmosphere at $8 \mathrm{kaBP}$ as derived from Berger (1978), (2) the zonally averaged monthly SST climatology from Levitus (1982), and (3) the reconstructed atmospheric $\mathrm{CO}_{2}$ concentration from the Taylor Dome ice core (260 ppmv). This spin-up represents the forcing conditions and a quasi-equilibrium state at $8 \mathrm{ka} \mathrm{BP}$. The 
Schematic Diagram of Preindustrial Global Carbon Cycles

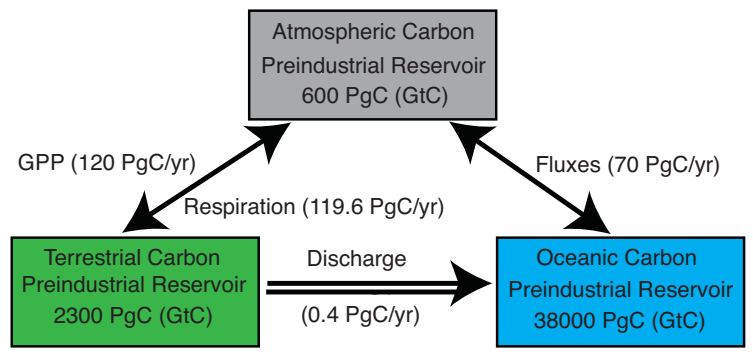

Fig. 2. Schematic diagram of pre-industrial global C cycles based on Chapter Seven of the recent Intergovernmental Panel on Climate Change report (Denman et al., 2007).

ocean component is next coupled with the aforementioned four components using flux adjustments (Wang and Mysak, 2000). The final equilibrium state of $8 \mathrm{ka} \mathrm{BP}$ is reached after an additional 5000 years integration.

To set up the model for the three types of transient simulations (see Table 1), the "Green" MPM is first spun up for 5060 years to reach the $8 \mathrm{ka}$ equilibrium state as described above. The model is then integrated from 8 to $0 \mathrm{kaBP}$ with varying solar forcing as prescribed by Berger (1978), the reconstructed atmospheric $\mathrm{CO}_{2}$ concentration from the Taylor Dome ice core (Fig. 1), a prescribed retreating LIS as in WMR, and an interactive vegetation. We modeled the carbon accumulation in NP as a separate, "inert" C reservoir. To account for this $\mathrm{C}$ accumulation while not changing the global VECODE NPP, we reduced the NPP in VECODE by the annual $\mathrm{C}$ accumulation rate in $\mathrm{NP}(\sim 0.03 \mathrm{PgC} / \mathrm{yr})$ in two of the three sensitivity simulations: (1) AOVI denotes the "control" run, in which we neglected the impact of the NP development on the NPP in VECODE; (2) $\mathrm{AOVI}_{b}$ denotes the "boreal" impact run, in which we have reduced all boreal NPP in VECODE proportionally to compensate for the $\mathrm{C}$ stored in NP, i.e., so that adjusted boreal NPP plus NP C accumulation equals the original boreal NPP (boreal defined here as all land north of $50^{\circ} \mathrm{N}$ ); and (3) $\mathrm{AOVI}_{g}$ denotes the "global" impact run, in which we have reduced the global NPP proportionally in VECODE to compensate for the C stored in NP. Note that: (1) the ice sheet component of the "Green" MPM is not interactive in any of these simulations; (2) the Greenland Ice Sheet is prescribed and fixed (Huybrechts, 2002); (3) the vegetation component is interactive in all these simulations; and (4) the global annual NPP flux (unit PgC/yr) in VECODE is calculated based on the area-integrated grid-cell NPP fluxes (unit $\mathrm{PgC} / \mathrm{yr} / \mathrm{area}$ ). We do not include anthropogenic land use and/or land cover changes in the simulations.

\section{Prescribed Peatland growth in the Holocene}

Throughout the Holocene, the NP have accumulated $\mathrm{C}$ (Smith et al., 2004; MacDonald et al., 2006; Roulet et al., 2007; Frolking and Roulet, 2007) with estimated presentday storages of $270-450 \mathrm{PgC}$. The assessment of the NP can be evaluated through the initiation (basal) dates (radiocarbon date of the deepest/oldest peat). Recent studies have advanced our understanding of Holocene NP dynamics in Western Siberia (Kremenetski et al., 2003; Smith et al., 2004), North America (Halsey et al., 1998; Gorham et al., 2007), and Finland (Korhola et al., 1995; Turunen et al., 2002). Figure 3 shows the relative basal date frequencies as determined from the above studies during the last deglaciation. To generate the total percentage of frequency, we have assumed a relative area weighting of 10:5:1 for Western Siberia, North America, and Finland (Frolking and Roulet, 2007), respectively. To simplify our prescribed NP development during the Holocene, we have assumed that (1) the NP expansion is proportional to observed basal date frequency, and the total area is thus calculated as a linear function of basal dates (Fig. 3, total frequency); and (2) the C uptake rate per unit area is and has been constant, and thus the total $\mathrm{C}$ uptakes scale linearly with peatland area (Frolking and Roulet, 2007).

The NP initiation starts earlier than $12 \mathrm{ka} \mathrm{BP}$ (MacDonald et al., 2006; Gorham et al., 2007), but the most rapid spread of the NP starts around $12 \mathrm{kaBP}$ (MacDonald et al., 2006). Based on reconstructed basal dates (Turunen et al., 2002; Smith et al., 2004; Gorham et al., 2007), it has been argued that the NP grows quasi-linearly with time (Fig. 3, total frequency). Furthermore, we have estimated the relative accumulation of peat from 8 to $0 \mathrm{ka} \mathrm{BP}$ to be about $180-300 \mathrm{PgC}$ (two thirds of the total accumulated peat over the past $12 \mathrm{ka}$ ). To reflect the uncertainty in the present-day NP C estimation, we have chosen three values (high, $450 \mathrm{PgC}$; middle, $360 \mathrm{PgC}$; and low, $270 \mathrm{PgC}$ ) as our prescribed present-day peat $\mathrm{C}$, which provides three different trajectories in our prescribed NP development from 12 to $0 \mathrm{ka} \mathrm{BP}$ (Fig. 4). We have applied the relative peat $\mathrm{C}$ changes (unit $\mathrm{PgC} / \mathrm{yr}$ ) from 8 to $0 \mathrm{kaBP}$ in our three-type transient simulations. In addition, because of the development of peatlands, the NPP flux (unit $\mathrm{PgC} / \mathrm{yr} / \mathrm{area}$ ) in VECODE has been compensated (reduced) according to Sect. 2.3 so that the area-integrated reduction of the NPP is balanced by the rates of peat $\mathrm{C}$ increases (unit $\mathrm{PgC} / \mathrm{yr}$ ).

Our prescribed NP development is highly idealized, and may not represent the true evolution of Holocene peatlands. One of the major concerns is that some parts of the NP (e.g., the Hudson Bay Lowlands) are excluded in our study because accurate basal dates are not yet available. In addition, the rate of peat $\mathrm{C}$ accumulation is a function of the changes in the relationship between the rate of production of new peats and the rate of decomposition of dead material. Those changes are, in turn, a function of external climatic influences and/or 
Table 1. Summary of the three types of transient simulations.

\begin{tabular}{cccccc}
\hline Acronym & Orbital parameters & $\mathrm{CO}_{2}$ in climate model (ppmv) & $\mathrm{CO}_{2}$ in VECODE (ppmv) & LIS $^{\mathrm{a}}$ & Impact of NP $^{\mathrm{b}}$ \\
\hline $\mathrm{AOVI}^{\mathrm{c}}$ & Variable & From Taylor Dome & From Taylor Dome & Retreating & None \\
$\mathrm{AOVI}_{b} \mathrm{c}$ & Variable & From Taylor Dome & From Taylor Dome & Retreating & Boreal \\
$\mathrm{AOVI}_{g}{ }^{\mathrm{c}}$ & Variable & From Taylor Dome & From Taylor Dome & Retreating & Global \\
\hline
\end{tabular}

a LIS denotes Laurentide Ice Sheet.

${ }^{b}$ NP denotes Northern Peatland. The development of the NP will affect the net primary productivity in VECODE.

${ }^{\mathrm{c}}$ See text in Sect. 2.3 for detailed definitions.

$\mathrm{d}$ The boreal region is defined as north of $50^{\circ} \mathrm{N}$ in the model.

allogenic controls (Hilbert et al., 2000; Roulet, 2000; Charman, 2002; Frolking and Roulet, 2007). For example, in an 8-ka core from a Western Canadian fen, Yu et al. (2003) found that the $\mathrm{C}$ accumulation rate increased during the wet Holocene periods. A recent study of Yu et al. (2009) shows that the estimated $\mathrm{C}$ accumulation at $8 \mathrm{kaBP}$ is about $73-$ $98 \mathrm{PgC}$, which is similar to our study and previous estimates (29-58 PgC by MacDonald et al., 2006; 92 PgC by Adams and Faure, 1998).

The simulated global NPP (Fig. 5) increases slightly from 60.5 to $61.2 \mathrm{PgC} / \mathrm{yr}$ from 8 to $6 \mathrm{kaBP}$ in response to a retreating LIS. The simulated boreal forest also expands in association with a retreating LIS and higher summer insolation in the mid-Holocene (figure not shown, see Wang et al., 2005b and WMR for more details). The subsequent global NPP decrease (Fig. 5) is caused primarily by the desertification in North Africa where the green Sahara/Sahel gradually becomes a semi-dry desert (figure not shown, see Wang et al., 2005b and WMR for more details). Because of the NP development, the global NPP has been compensated (reduced) slightly in $\mathrm{AOVI}_{b}$ and $\mathrm{AOVI}_{g}$ simulations. However, the overall trends are similar as compared with AOVI run. Notice that we only plot the simulations with a prescribed high present-day NP C value $(450 \mathrm{PgC})$ in Fig. 4, which provides the most significant impact of the NP development on the vegetation module (VECODE) in the "Green" MPM. For the mid- and low-values ( 360 and $270 \mathrm{PgC}$ ) of the presentday NP, the simulated global NPP curves are similar to those in Fig. 5.

As occurs with the global NPP evolution, the simulated global terrestrial C (Fig. 6), including global biomass and soil $\mathrm{C}$, increases from 2132 to $2158 \mathrm{PgC}$ from 8 to $6 \mathrm{ka} \mathrm{BP}$ due to a retreating LIS and an expanded boreal forest under higher summer insolation. Subsequently, the global terrestrial C (Fig. 6) decreases from the peak in mid-Holocene (6 ka BP) to a minimum value of about $2090 \mathrm{PgC}$ at the end of the preindustrial period (hereafter, $0 \mathrm{kaBP}$ ). The mid-Holocene climatic optimum is well simulated in the model. As shown in WMR, the desertification of North Africa decreases terrestrial $\mathrm{C}$ there by about $50 \mathrm{PgC}$, which explains around $75 \%$ of the total peak-peak terrestrial $\mathrm{C}$ changes from 6 to $0 \mathrm{kaBP}$

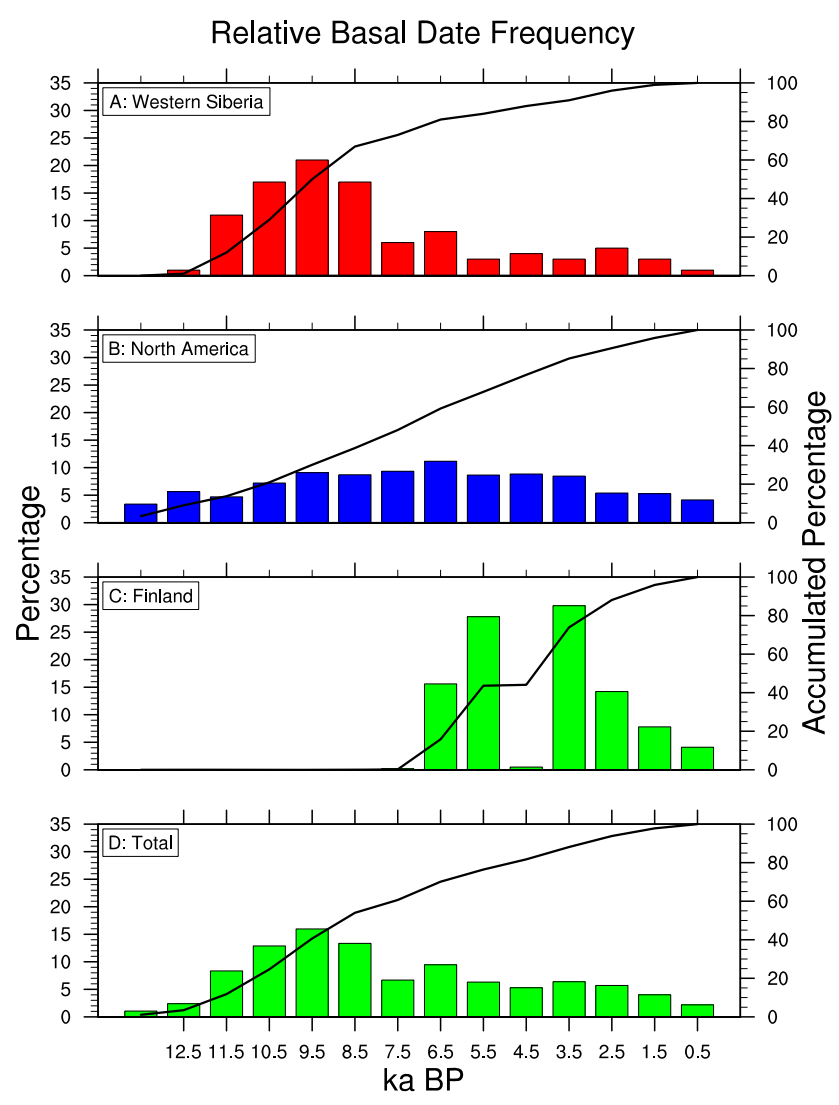

Fig. 3. Summary of observed relative basal date frequency for (a) Western Siberia (Smith et al., 2004), (b) North America (Halsey et al., 1998; Gorham et al., 2007), (c) Finland (Turunen et al., 2002), and (d) Total. To estimate the total frequency, we have used an area weighting of 10:5:1 for Western Siberia, Western Canada, and Finland, respectively (Frolking and Roulet, 2007). The solid black curves in the panels represent the accumulated peatland fractions (or percentages).

(figure not shown, see WMR for more details). In addition, we have simulated a slight terrestrial C increase in the Southern Hemisphere throughout the Holocene from 8 to $0 \mathrm{kaBP}$, which is attributed to the increasing summer insolation over the same period (WMR). Again, we only plot the simulations 


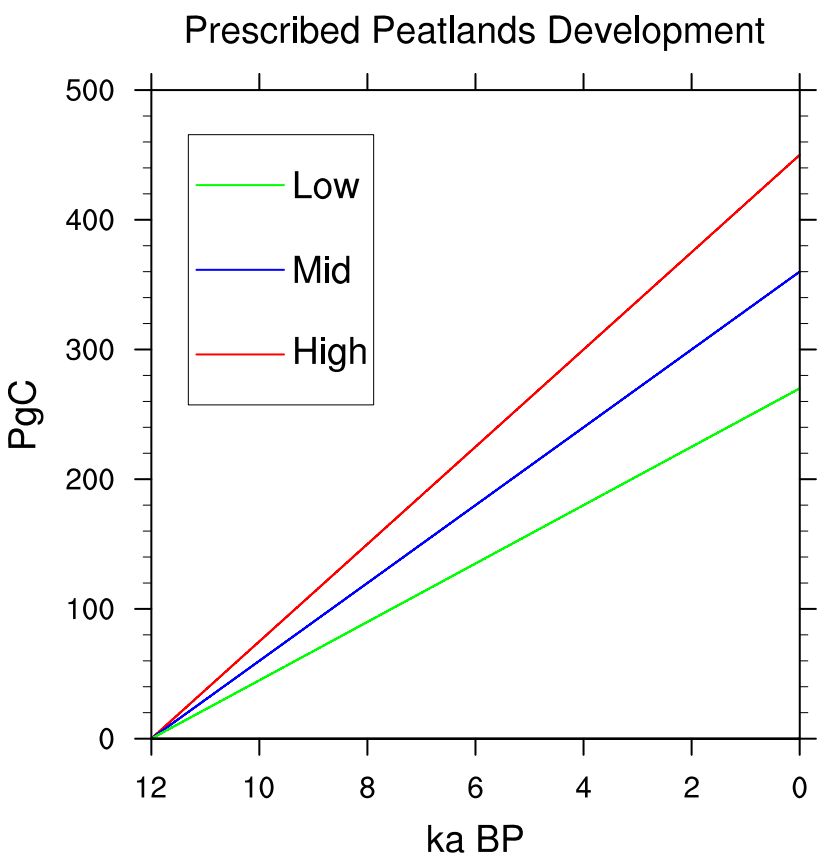

Fig. 4. Prescribed peatlands development in the model. To reflect the uncertainty of the present-day estimated peat $\mathrm{C}$ in the NP, we have applied three different values (high: $450 \mathrm{PgC}$, mid: $360 \mathrm{PgC}$, and low: $270 \mathrm{PgC}$ ) as the $\mathrm{C}$ storage of the NP. We assume a linearized slow development of the NP, which corresponds to the total basal date frequency as shown in Fig. 3d.

for a prescribed high present-day NP C value as in Fig. 5, which provides the most significant influence of the NP development in simulated global terrestrial $\mathrm{C}$ in the $\mathrm{AOVI}_{b}$ and $\mathrm{AOVI}_{g}$ transient simulations. For the mid and low values, the simulated global terrestrial $\mathrm{C}$ curves are similar to those in Fig. 6.

Overall, gradual development of the NP, as prescribed in the model, has only negligible influences on the simulated NPP and terrestrial C cycles. This is primarily due to the slow build-up of the NP as prescribed in the model $(\sim 0.03 \mathrm{PgC} / \mathrm{yr})$. We expect that any abruptness in the NP development would have a substantiative impact on the terrestrial $\mathrm{C}$ cycle dynamics over a short period. However, over millennial timescales, we do not expect a significant impact of the NP on terrestrial $\mathrm{C}$ cycle dynamics, which are controlled presumably by the simulated climate conditions, atmospheric $\mathrm{CO}_{2}$ concentration, and anthropogenic land-use and/or land-cover changes (Ruddiman's hypothesis) during the Holocene.

The global SST (Fig. 7) increases slowly under the retreating LIS, which overrides the orbital-induced cooling, and the radiative forcing of atmospheric $\mathrm{CO}_{2}$ until about $1 \mathrm{ka} B$ P. After that, a strong SST cooling is caused presumably by the drop in atmospheric $\mathrm{CO}_{2}$ concentration. The global peakto-peak increase of SST is about $0.2^{\circ} \mathrm{C}$ in the three types of transient simulations (AOVI, $\mathrm{AOVI}_{b}$, and $\mathrm{AOVI}_{g}$ ). Because

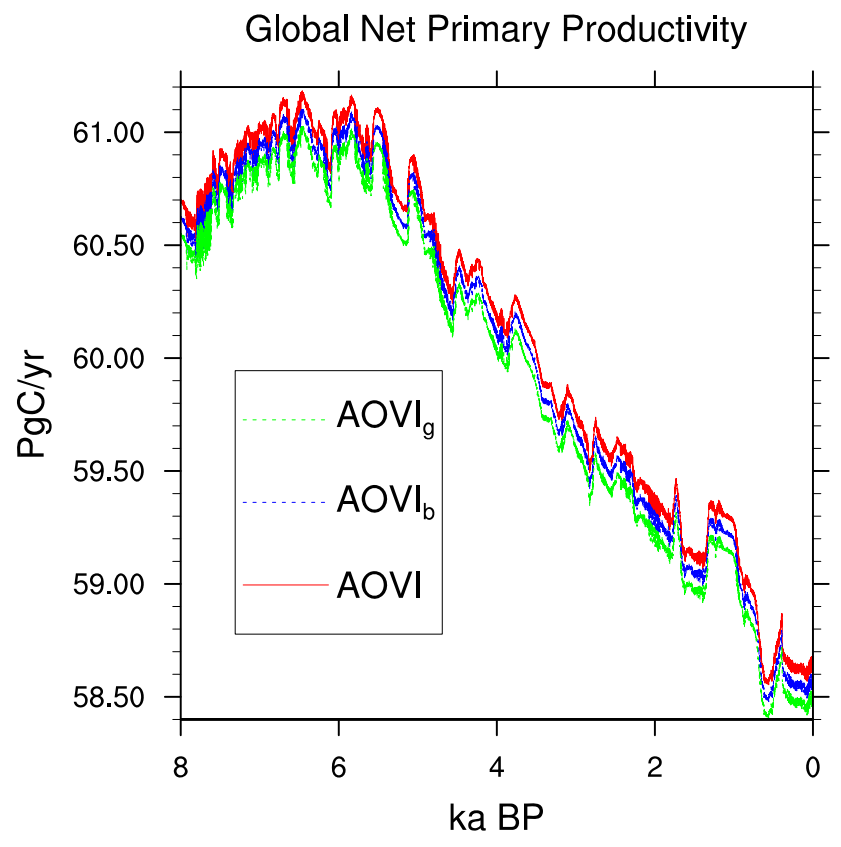

Fig. 5. Simulated global net primary productivity from threetype transient simulations of the "Green" MPM, in which the high present-day peat value $(450 \mathrm{PgC})$ is used in the prescribed NP development. For other values, the curves look similar. The AOVI run is considered as the "control" experiment, while the $\mathrm{AOVI}_{b}$ and $\mathrm{AOVI}_{g}$ are two sensitivity simulations, in which the NPP in the vegetation module is compensated by the development of NP as described in Sect. 3.

these three SST curves are almost identical, we have shifted upward the curves for the $\mathrm{AOVI}_{b}$ and $\mathrm{AOVI}_{g}$ simulations by $0.1^{\circ} \mathrm{C}$ and $0.2^{\circ} \mathrm{C}$, respectively. Because of the similarity, we do not show the SST plots for the mid and low prescribed present-day peat $\mathrm{C}$ values. Overall, we find the prescribed NP development has negligible impact on the evolution of the SST during the Holocene period from 8 to $0 \mathrm{ka} \mathrm{BP}$. With such a small magnitude of SST increase, we do not expect a substantiative $\mathrm{CO}_{2}$ outgassing from the sea surface during the Holocene (Brovkin et al., 2002, 2008).

Based on our three NP development trajectories and three types of model simulations, we have estimated the relative $\mathrm{C}$ storage changes in land (VECODE plus prescribed NP trajectories, green curves), atmosphere (ice core data, blue curves), and ocean (red curves, assuming a global $\mathrm{C}$ conservation during the Holocene) (Fig. 8). It is clear that, without considering the human land-use/land-cover changes (Ruddiman, 2008), the inclusion of the NP has sequestered a large amount of $\mathrm{C}$ from both the atmosphere and ocean (presumably deep ocean), which significantly changes the conclusions of WMR. Because of the NP C sequestration, small variations of terrestrial $\mathrm{C}$ in VECODE are fading out. The only remaining detectable signal is the oceanic $\mathrm{C}$ source during the Holocene from 8 to $0 \mathrm{kaBP}$. We note, however, 


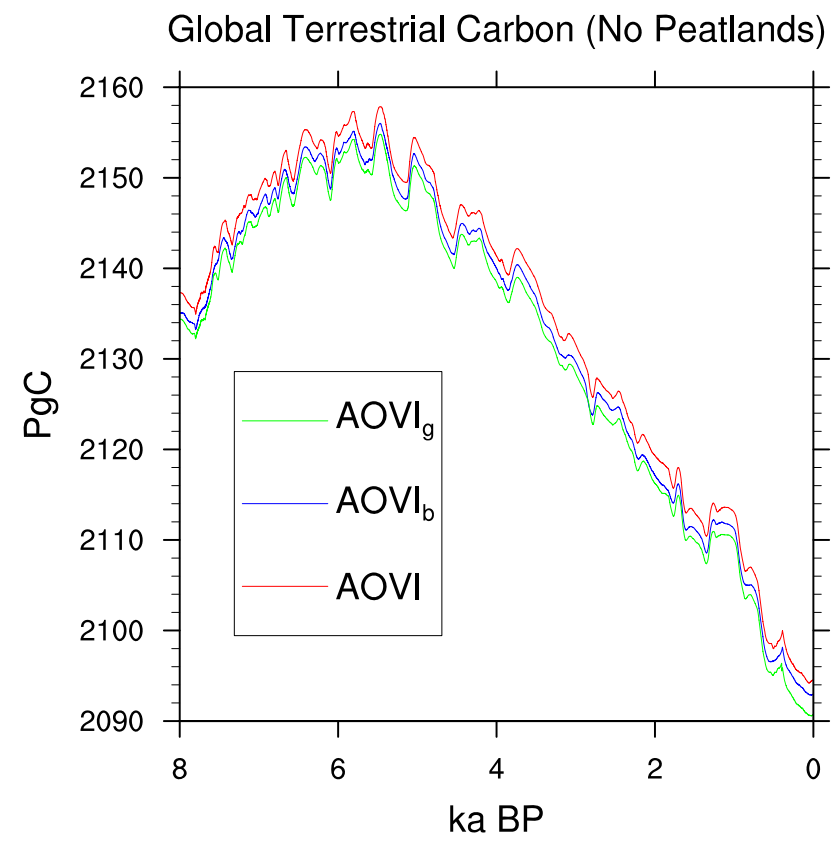

Fig. 6. Simulated global terrestrial $C$ from three-type transient simulations of the "Green" MPM, in which the high present-day peat value $(450 \mathrm{PgC})$ is used in the prescribed NP development. For other values, the curves look similar. Note that the global terrestrial $\mathrm{C}$ includes global biomass and soil $\mathrm{C}$, but does not include the peatland C. Again, three-type experiments (see Sect. 2.3 and Table 1 for details) are carried out for the sensitivity of NP development over the vegetation module.

that if the anthropogenic land-use and/or land-cover changes are considered together with the NP development during the Holocene, Fig. 8 would be changed. We also note that for a specific NP accumulation scenario, there are very little differences among three types of model simulations. This is because that VECODE model is confined to simulate the evolution of carbon storage on land by climatic forcings.

\section{Results}

\section{Summary, discussion, and future work}

The study of WMR found that the first 10-ppmv $\mathrm{CO}_{2}$ rise in the atmosphere from 8 to $6 \mathrm{ka}$ BP came from the ocean. Applying additional assumptions (Joos et al., 2004), WMR further derived that the second 10-ppmv $\mathrm{CO}_{2}$ rise from 6 to $0 \mathrm{ka} \mathrm{BP}$ came from both land (5-7 ppmv) and ocean (35 ppmv). However, based on the three types of transient simulations using the "Green" MPM, and three prescribed linear growths of the NP, we have found, without additional assumptions, that the oceanic $\mathrm{C}$ reservoir is the primary source of the 20 ppmv $\mathrm{CO}_{2}$ increase in the atmosphere over the past 8000 years (Broecker et al., 2001; Broecker and Clark, 2003). This is because the terrestrial pool, together with the atmo-

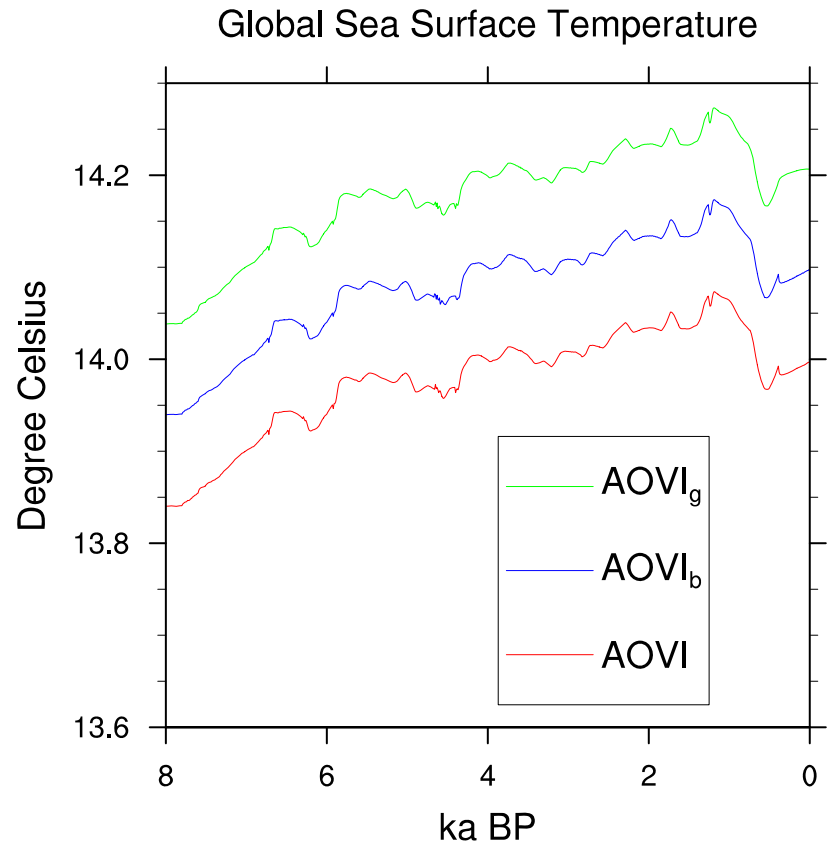

Fig. 7. Simulated global sea surface temperature from three-type transient simulations of the "Green" MPM, in which a high presentday peat value $(450 \mathrm{PgC})$ is used in the prescribed NP development. Note that we do not consider the small Holocene radiative warming by the emission of methane from the NP (Frolking and Roulet, 2007). Because these three curves are overlapping each other, we have shifted the curves upward for $\mathrm{AOVI}_{b}$ and $\mathrm{AOVI}_{g}$ by $0.1^{\circ}$ and $0.2^{\circ}$, respectively.

sphere become the $\mathrm{C}$ sink during the Holocene. Our study provides a first-order quantification of the importance of NP in Holocene $\mathrm{C}$ cycle dynamics. However, there are a few caveats associated with our current study, which provides the guidance for future studies of peatlands and Holocene $\mathrm{C}$ cycle dynamics.

First, our prescribed NP development is highly idealized, and is based on the present-day estimation of total peat $\mathrm{C}$, and previous studies of peatland initiation dates in Western Siberia (Smith et al., 2004), North America (Halsey et al., 1998; Gorham et al., 2007), and Finland (Korhola et al., 1995; Turunen et al., 2002). Some large portions of the NP are still not well constrained by basal dates. In particular, it is believed that the age of the Hudson Bay Lowlands may be younger than other peatlands, which will shift the overall $\mathrm{C}$ uptake into a later time in the Holocene. Second, even with well-constrained basal dates, the bulk $\mathrm{C}$ accumulation rates may be varying with climatic and biogeographic conditions (Yu et al., 2003; Belyea and Malmer, 2004; Yu et al., 2009), although Gorham et al. (2003) indicated a relative constant long-term $\mathrm{C}$ accumulation rate. Third, we have neglected the radiative forcing of methane $\left(\mathrm{CH}_{4}\right)$ emitted from the NP development, which has been estimated at roughly $0.05-0.1 \mathrm{~W} / \mathrm{m}^{2}$ through the Holocene (Frolking and Roulet, 


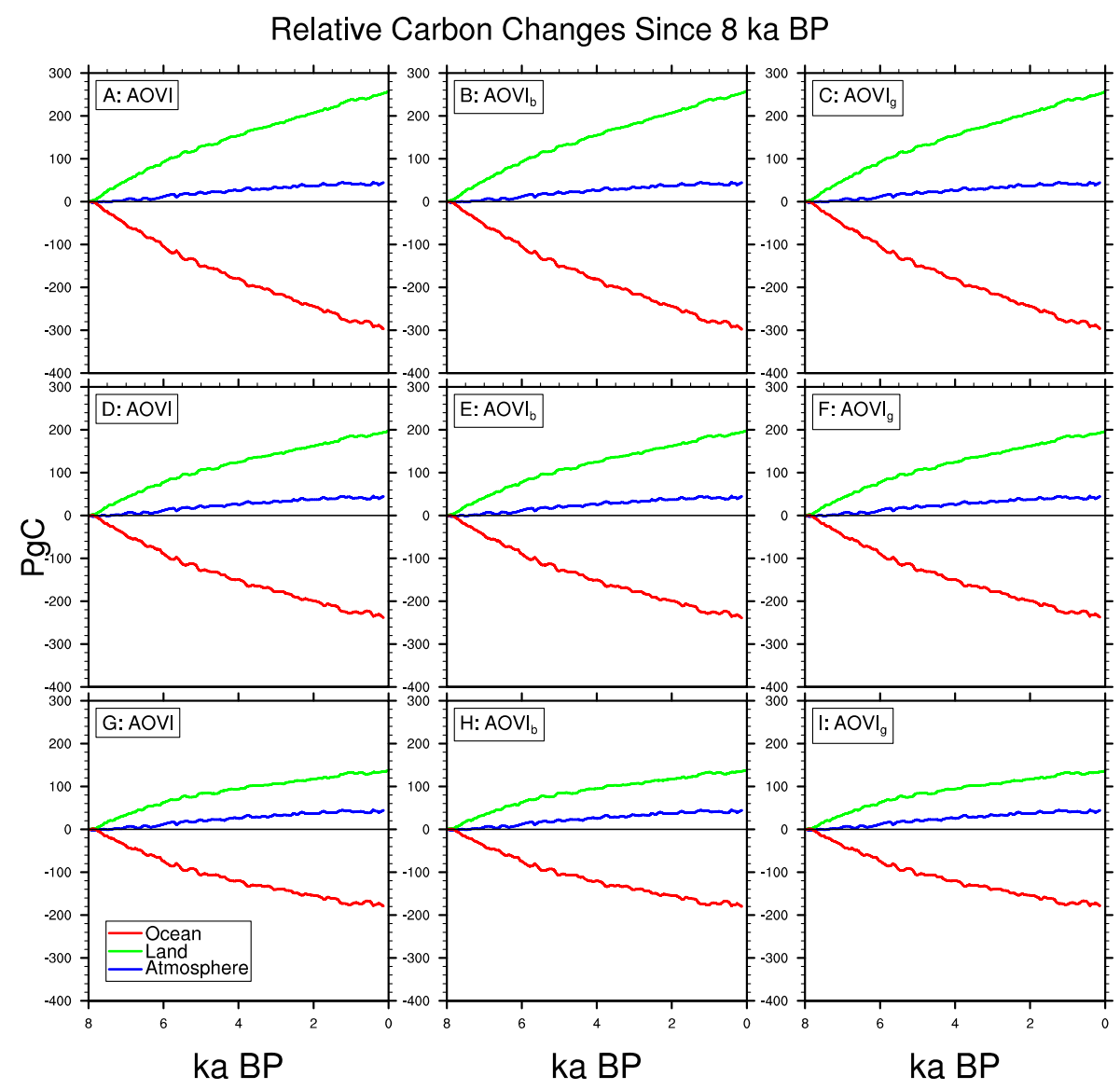

Fig. 8. Relative $\mathrm{C}$ storage changes from nine transient simulations. Assuming global $\mathrm{C}$ conservation during the Holocene period from 8 to $0 \mathrm{kaBP}$, we derived the corresponding ocean $\mathrm{C}$ changes (red curves) to compensate the relative $\mathrm{C}$ changes in both atmosphere (blue curves) and land (including the NP, green curves). Top row corresponds to the high present-day peat value (450 PgC); middle row corresponds to the middle present-day peat value $(360 \mathrm{PgC})$; and bottom row corresponds to the low present-day peat value $(270 \mathrm{PgC})$. We have assumed a pre-industrial $(0 \mathrm{kaBP})$ atmospheric $\mathrm{CO}_{2}$ concentration of 283 ppmv in the calculation of atmospheric $\mathrm{C}$ changes.

2007). Forth, we believe that the radiative forcing of $\mathrm{N}_{2} \mathrm{O}$ is less than those of $\mathrm{CO}_{2}$ and $\mathrm{CH}_{4}$ (Fluckiger et al., 2002), therefore is neglected also in our study. Finally, we have also neglected the freshwater forcing from LIS melt. However, we believe that the freshwater from the gradual retreating LIS has limited impact on the ocean circulation and terrestrial $\mathrm{C}$ cycle dynamics after the $8.2 \mathrm{ka}$ BP "cold" event (Alley et al., 1997; Wang and Mysak, 2005d; Wang, 2005).

Although we rely on the clear, robust ice-core-retrieved atmospheric $\mathrm{CO}_{2}$ concentration for our inverse method, we believe that the $\delta^{13} \mathrm{C}$ signal derived from ice core during the Holocene is not well constrained due to the small signal ( 0.2 $\%$ ) to measurement error $\left(0.06^{\circ} / 00\right)$ ratio (Broecker et al., 2001; Kaplan et al., 2002), and the scatter of the results (0.08 $\%$ ) around the model curve (Broecker et al., 2001). Furthermore, in a previous study using asynchronously coupled simulations of glacial-interglacial terrestrial carbon cycle dynamics, Kaplan et al. (2002) suggested that the land overall continued to increase in carbon content throughout the Holocene with an estimated value of $240 \mathrm{PgC}$. This land car- bon increase is within the range of our prescribed NP growth and simulated land carbon changes (Fig. 8) when the uncertainties of Kaplan et al. (2002) are considered.

It also should be noted that we have not attempted to include the anthropogenic land-use and/or land-cover changes during the Holocene (Ruddiman, 2003, 2006, 2007, 2008). We believe that the magnitude of these unknown changes and their biogeophysical and biogeochemical consequences are not well-constrained yet. However, with a detailed reconstruction of human impact on terrestrial $\mathrm{C}$ cycle, we could generate a different picture of Holocene $\mathrm{C}$ cycle dynamics based on our inverse method. Nevertheless, our fundamental goal is to introduce interactively coupled oceanic and peatland C cycle modules into the "Green" MPM. By doing that, we will have the capability to simulate the evolution $C$ cycle in the Holocene, and hence gain insights into the details of the oceanic and peatland $\mathrm{C}$ processes. 
Acknowledgements. During the course of our research, we have benefited from discussions with W. Ruddiman and Z. Yu. Our research has been supported by the Canadian Foundation of the Canadian Foundation for Climate and Atmospheric Sciences (CFCAS), the Natural Sciences and Engineering Research Council of Canada (NSERC), and the US National Science Foundation (NSF ATM-0628399). Yi Wang is also supported by the K. C. Wong Education Foundation of Chinese Academy of Sciences. The model simulations were carried out at the National Energy Research Scientific Computing Center and Argonne Leadership Computing Facility of the US DOE, and EMSL, a national scientific user facility sponsored by the US DOE's Office of Biological and Environmental Research located at Pacific Northwest National Laboratory. We thank four reviewers for their thoughtful comments.

Edited by: V. Rath

\section{References}

Adams, J. M. and Faure, H.: A new estimate of changing carbon storage on land since the last glacial maximum, based on global land ecosystem reconstruction, Global Planet. Change, 16-17, 3-24, 1998.

Alley, R. B., Mayewski, P. A., Sowers, T., Stuiver, M., Taylor, K. C., and Clark, P. U.: Holocene climate instability: A prominent, widespread event 8200 yr ago, Geology, 25, 483-486, 1997.

Bacastow, R. B.: The effect of temperature change of the warm surface waters of the oceans on atmospheric $\mathrm{CO}_{2}$, Global Biogeochem. Cy., 10, 319-333, 1996.

Barber, K. E., Chambers, F. M., and Maddy, D.: Holocene palaeoclimates from peat stratigraphy: macrofossil proxy climate records from three oceanic raised bogs in England and Ireland, Quaternary Sci. Rev., 22, 521-539, 2003.

Beerling, D.: The role of the terrestrial biosphere in Holocene carbon cycle dynamics, Global Ecol. Biogeogr., 9, 421-429, 2000.

Belyea, L. R. and Malmer, N.: Carbon sequestration in peatland: patterns and mechanisms of response to climate change, Global Change Biol., 10, 1043-1052, 2004.

Berger, A. L.: Long-term variations of daily insolation and Quaternary climatic changes, J. Atmos. Sci., 35, 2362-2367, 1978.

Broecker, W. S. and Clark, E.: Holocene atmospheric $\mathrm{CO}_{2}$ increase as viewed from the seafloor, Global Biogeochem. Cy., 17, 1052, doi:10.1029/2002GB001985, 2003.

Broecker, W. S. and Stocker, T.: The Holocene $\mathrm{CO}_{2}$ rise: Anthropogenic or natural?, EOS, EOS, 87, 27, 2006.

Broecker, W. S., Clark, E., McCorkle, D. C., Peng, T.-H., Hajdas, I., and Bonani, G.: Evidence for a reduction in carbonate ion content of the deep sea during the course of the Holocene, Paleoceanography, 14, 744-752, 1999.

Broecker, W. S., Lynch-Stieglitz, J., Clark, E., Hajdas, I., and Bonani, G.: What caused the atmosphere's $\mathrm{CO}_{2}$ content to rise during the last 8000 years?, Geochem. Geophy. Geosy., 2, 1062, doi:10.1029/2001GC000177, 2001.

Brovkin, V., Ganopolski, A., and Svirezhev, Y.: A continuous climate-vegetation classification for use in climate-biosphere studies, Ecol. Model., 101, 251-261, 1997.

Brovkin, V., Bendtsen, J., Claussen, M., Ganopolski, A., Kubatzki, C., Petoukhov, V., and Andreev, A.: Carbon cycle, Vegeta- tion and Climate Dynamics in the Holocene: Experiments with the CLIMBER-2 Model, Global Biogeochem. Cy., 16, 1139, doi:10.1029/2001GB001662, 2002.

Brovkin, V., Kim, J., Hofmann, M., and Schneider, R.: A lowering effect of reconstructed Holocene changes in sea surface temperature on the atmospheric $\mathrm{CO}_{2}$ concentration, Global Biogeochem. Cy., 22, GB1016, doi:10.1029/2006GB002885, 2008.

Charman, D.: Peatlands and Environmental Change, John Wiley and Sons, Chichester, UK, 312 pp., 2002.

Claussen, M., Mysak, L. A., Weaver, A. J., et al.: Earth system models of intermediate complexity: closing the gap in the spectrum of climate system models, Clim. Dyn., 18, 579-586, 2002.

Cochelin, A.-S. B., Mysak, L. A., and Wang, Z.: Simulation of long-term future climate changes with the Green McGill Paleoclimate Model: The next glacial inception, Climatic Change, 79, 381-401, 2006.

Denman, K. L., Brasseur, G., Chidthaisong, A., et al.: Couplings Between Changes in the Climate System and Biogeochemistry, chap, in: Climate Change 2007: The Physical Science Basis. Contribution of Working Group I to the Fourth Assessment Report of the Intergovernmental Panel on Climate Change, Cambridge University Press, Cambridge, UK and New York, NY, USA, 7, 499-588, 2007.

Dyke, A. S. and Prest, V. K.: Late Wisconsinan and Holocene retreat of the Laurentide Ice Sheet, Geological Survey Canada, map 1702A, 1:500 0000, 1986.

Dyke, A. S. and Prest, V. K.: Late Wisconsinan and Holocene history of the Laurentide ice sheet, Geogr. Phys. Quatern., 41, 237264, 1987.

Falloon, P., Smith, P., Colemand, K., and Marshall, S.: Estimating the size of the inert organic matter pool from total soil organic carbon content for use in the Rothamsted Carbon Model, Soil Biol. Biochem., 30, 1207-1211, 1998.

Fluckiger, J., Monnin, E., Stauffer, B., Schwander, J., Stocker, T. F., Chappellaz, J., Raynaud, D., and Barnola, J.-M.: Highresolution Holocene $\mathrm{N}_{2} \mathrm{O}$ ice core record and its relationship with $\mathrm{CH}_{4}$ and $\mathrm{CO}_{2}$, Global Biogeochem. Cy., 16, 1010, doi:10.1029/2001GB001417, 2002.

Frolking, S. and Roulet, N. T.: Holocene radiative forcing impact of northern peatland carbon accumulation and methane emissions, Glob. Change. Biol., 13, 1079-1088, 2007.

Frolking, S., Roulet, N. T., and Fuglestvedt, J.: How northern peatlands influence the Earth's radiative budget: Sustained methane emission versus sustained carbon sequestration, J. Geophys. Res., 111, G01 008, doi:10.1029/2005JG000091, 2006.

Gajewski, K., Viau, A., Sawada, M., Atkinson, D., and Wilson, S.: Sphagnum peatland distribution in North America and Eurasia during the past 21000 years, Global Biogeochem. Cy., 15, 297310, 2001.

Gorham, E.: The development of peat lands, Q. Rev. Biol., 32, 154166, 1957.

Gorham, E.: Northern peatlands: Role in carbon cycle and probable response to climatic warming, Ecol. Appl., 1, 182-195, 1991.

Gorham, E.: The biogeochemistry of northern peatlands and its possible response to global warming, in: Biotic Feedbacks in the Global Climatic System: Will the Warming Speed the Warming?, edited by: Woodwell, G. and MacKenzie, F., Oxford Univ. Press, New York, 169-187, 1995.

Gorham, E., Janssens, J. A., and Glaser, P. H.: Rates of peat 
accumulation during the postglacial period in 32 sites from Alaska to Newfoundland with special emphasis on norther Minnesota, Can. J. Botany., 81, 429-438, 2003.

Gorham, E., Lehman, C., Dyke, A., Janssens, J., and Dyke, L.: Temporal and spatial aspects of peatland initiation following deglaciation in North America, Quaternary Sci. Rev., 26, 300311, doi:10.1016/j.quascirev.2006.08.008, 2007.

Halsey, L. A., Vitt, D. H., and Bauer, I. K.: Peatland initiation during the Holocene in continental Western Canada, Climatic Change, 40, 315-342, 1998.

Hilbert, D. W., Roulet, N. T., and Moore, T. R.: Modelling and analysis of peatlands as dynamical systems, J. Ecol., 88, 230242, 2000.

Huybrechts, P.: Sea-level changes at the LGM from ice-dynamic reconstructions of the Greenland and Antarctic ice sheets during the glacial cycles, Quaternary Sci. Rev., 21, 203-231, 2002.

Indermühle, A., Stocker, T. F., Joos, F., Fischer, H., Smith, H. J., Wahlen, M., Deck, B., Mastroianni, D., Tschumi, J., Blunier, T., Meyer, R., and Stauffer, B.: Holocene carbon-cycle dynamics based on $\mathrm{CO}_{2}$ trapped in ice at Taylor Dome, Antarctica, Nature, 398, 121-126, 1999.

Joos, F., Gerber, S., Prentice, I. C., Otto-Bliesner, B. L., and Valdes, P. J.: Transient simulation of Holocene atmospheric carbon dioxide and terrestrial carbon since the Last Glacial Maximum, Global Biogeochem. Cy., 18, GB2002, doi:10.1029/2003GB002156, 2004.

Kaplan, J. O., Prentice, I. C., Knorr, W., and Valdes, P. J.: Modeling the dynamics of terrestrial carbon storage since the Last Glacial Maximum, Geophys. Res. Lett., 29, 2074, doi:10.1029/2002GL015230, 2002.

Korhola, A., Tolonen, K., Turunen, J., and Jungner, H.: Estimating long-term carbon accumulation rates in boreal peatlands by radiocarbon dating, Radiocarbon, 37, 575-584, 1995.

Kremenetski, K. V., Velichko, A. A., Borisova, O. K., MacDonald, G. M., Smith, L. C., Frey, K. E., and Orlova, L. A.: Peatlands of the Western Siberian lowlands: current knowledge on zonation, carbon content and late quaternary history, Quaternary Sci. Rev., 22, 703-723, 2003.

Levitus, S.: Climatological Atlas of the World Ocean, Tech. rep., NOAA Professional Paper 13, US Government Printing Office, Washington, DC, 1982.

Limpens, J., Berendse, F., Blodau, C., Canadell, J. G., Freeman, C., Holden, J., Roulet, N., Rydin, H., and Schaepman-Strub, G.: Peatlands and the carbon cycle: from local processes to global implications - a synthesis, Biogeosciences, 5, 1475-1491, 2008, http://www.biogeosciences.net/5/1475/2008/.

Lüthi, D., Floch, M. L., Bereiter, B., et al.: High-resolution carbon dioxide concentration record 650000-800000 years before present, Nature, 453, 379-382, doi:10.1038/nature06949, 2008.

MacDonald, G. M., Beilman, D. W., Kremenetski, K. V., Sheng, Y., Smith, L. C., and Velichko, A. A.: Rapid early development of circumarctic peatlands and atmospheric $\mathrm{CH}_{4}$ and $\mathrm{CO}_{2}$ variations, Science, 314, 285-288, 2006.

Monnin, E., Indermühle, A., Dällenbach, A., Flückiger, J., Stauffer, B., Stocker, T. F., Raynaud, D., and Barnola, J.: Atmospheric $\mathrm{CO}_{2}$ concentrations over the Last Glacial Termination, Science, 291, 112-114, 2001.

Moore, T. R., Roulet, N. T., and Waddington, J. M.: Uncertainty in predicting the effect of climatic change on the carbon cycling of
Canadian peatlands, Climatic Change, 40, 229-245, 1998.

Mysak, L. A.: Glacial inceptions: Past and future, Atmos Ocean, 46, 317-341, 2008.

Renssen, H., Brovkin, V., Fichefet, T., and Goose, H.: Simulation of the Holocene climate evolution in Northern Africa: The termination of the African Humid Period, Quatern. Int., 150, 95-102, doi:10.1016/j.quaint.2005.01.001, 2006.

Roulet, N. T.: Peatlands, carbon storage, greenhouse gases, and the Kyoto protocol: prospects and significance for Canada, Wetlands, 20, 605-615, 2000.

Roulet, N. T., Lafleurs, P. M., Richard, P. J. H., Moore, T. R., Humphreys, E. R., and Bubier, J.: Contemporary carbon balance and late Holocene carbon accumulation in a norther peatland, Glob. Change Biol., 13, 397-411, 2007.

Ruddiman, W.: The challenge of modeling interglacial $\mathrm{CO}_{2}$ and $\mathrm{CH}_{4}$ trends, Quaternary Sci. Rev., 27, 445-448, 2008.

Ruddiman, W. F.: The anthropogenic greenhouse era began thousands of years ago, Climatic Change, 61, 261-293, 2003.

Ruddiman, W. F.: On "The Holocene $\mathrm{CO}_{2}$ rise: Anthropogenic or natural?”, EOS, 87, 352, 2006.

Ruddiman, W. F.: The early anthropogenic hypothesis: Challenges and responses, Rev. Geophys., 45, RG4001, 2007.

Schimel, D. S., Braswell, B. H., Holland, E. A., McKeown, R., Ojima, D. S., Painter, T. H., Parton, W. J., and Townsend, A. R.: Climatic, edaphic and biotic controls over carbon and turnover of carbon in soils, Global Biogechem. Cy., 8, 279-293, 1994.

Smith, L., MacDonald, G., Velichko, A., Beilman, D., Borisova, O., Frey, K., Kremenetski, K., and Sheng, Y.: Siberian peatlands a net carbon sink and global methane source since the early Holocene, Science, 303, 353-356, 2004.

Turunen, J., Tomppo, E., Tolonen, K., and Reinikainen, A.: Estimating carbon accumulation rates of undrained mires in Finland: Application to boreal and subarctic regions, Holocene, 12, 6980, 2002.

Wang, Y.: Simulation of the climate, ocean, vegetation and terrestrial carbon cycle in the Holocene, Ph.D. thesis, McGill University, Department of Atmospheric and Oceanic Sciences, McGill University, 805 Sherbrooke Street West, Montreal, Quebec, Canada H3A 2K6, available as Centre for Climate and Global Change Research $\left(C^{2} G C R\right)$, Report No. 2005-3, 2005.

Wang, Y. and Mysak, L. A.: Response of the ocean, climate and terrestrial carbon cycle to Holocene freshwater discharge after $8 \mathrm{kyr}$ BP, Geophys. Res. Lett., 32, L15 705, doi:10.1029/2005GL023344, 2005d.

Wang, Y., Mysak, L. A., and Roulet, N. T.: Holocene climate and carbon cycle dynamics: Experiments with the "green" McGill Paleoclimate Model, Global Biogechem. Cy., 19, GB3022, doi:10.1029/2005GB002484, 2005c.

Wang, Y., Mysak, L. A., Wang, Z., and Brovkin, V.: The Greening of the McGill Paleoclimate Model. Part I: Improved Land Surface Scheme with Vegetation Dynamics, Clim. Dyn., 24, 469480, doi:10.1007/s00382-004-0515-9, 2005a.

Wang, Y., Mysak, L. A., Wang, Z., and Brovkin, V.: The Greening of the McGill Paleoclimate Model. Part II: Simulation of Holocene Millennial-Scale Natural Climate Changes, Clim. Dyn., 24, 481-496, doi:10.1007/s00382-004-0516-8, 2005 b.

Wang, Z. and Mysak, L. A.: A simple coupled atmosphere-oceansea ice-land surface model for climate and paleoclimate studies, J. Climate, 13, 1150-1172, 2000. 
Wang, Z. and Mysak, L. A.: Glacial abrupt climate changes and Dansgaard-Oeschger Oscillations in a coupled climate model, Paleoceanography, 21, PA2001, doi:10.1029/2005PA001238, 2006.

Wang, Z., Cochelin, A.-S. B., Mysak, L. A., and Wang, Y.: Simulation of the Last Glacial Inception with the Green McGill Paleoclimate Model, Geophys. Res. Lett., 32, L12 705, doi:10.1029/2005GL023047, 2005.

Wright, D. G. and Stocker, T. F.: A zonally averaged ocean model for the thermohaline circulation. I: Model development and flow dynamics, J. Phys. Oceanogr., 21, 1713-1724, 1991.

Yu, Z.: Holocene carbon accumulation of fen peatlands in Boreal Western Canada: A complex ecossytem response to climate variation and disturbance, Ecosystems, 9, 1278-1288, 2006.
Yu, Z., Campbell, I. D., Campbell, C., Vitt, D. H., Bond, G. C., and Apps, M. J.: Carbon sequestration in western Canadian peat highly sensitive to Holocene wet-dry climate cycles at millennial timescales, The Holocene, 13, 801-808, 2003.

Yu, Z. C., Beilman, D. W., and Jones, M.C.: Sensitivity of northern peatland carbon dynamics to Holocene climate change, in: Carbon Cycling in Northern Peatlands, edited by: Baird, A. J., Belyea, L. R., Comas, X., Reeve, A. S., and Slater, L. D., Geophysical Monograph 184, American Geophysical Union, Washington DC, USA, 55-69, doi:10.1029/2008GM000822 2009. 